\title{
Uptake of Inorganic and Organic Nitrogen Sources by Dinophysis acuminata and D. acuta
}

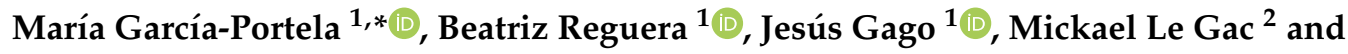 \\ Francisco Rodríguez ${ }^{1}$ (D) \\ 1 Spanish Institute of Oceanography (IEO), Oceanographic Center of Vigo, Subida a Radio Faro 50, Cabo Estay, \\ Canido, 36390 Vigo, Spain; beatriz.reguera@ieo.es (B.R.); jesus.gago@ieo.es (J.G.); \\ francisco.rodriguez@ieo.es (F.R.) \\ 2 Ifremer, DYNECO PELAGOS, 29280 Plouzané, France; mickael.le.gac@ifremer.fr \\ * Correspondence: mgp87@hotmail.es; Tel.: +34-637381507
}

Received: 17 December 2019; Accepted: 25 January 2020; Published: 29 January 2020

\begin{abstract}
Dinoflagellate species of Dinophysis are obligate mixotrophs that require light, nutrients, and prey for sustained growth. Information about their nitrogenous nutrient preferences and their uptake kinetics are scarce. This study aimed to determine the preferred nitrogen sources in cultures of D. acuminata and D. acuta strains from the Galician Rías Baixas (NW Spain) and to compare their uptake kinetics. Well-fed versus starved cultures of $D$. acuminata and $D$. acuta were supplied with $\mathrm{N}^{15}$ labeled inorganic (nitrate, ammonium) and organic (urea) nutrients. Both species showed a preference for ammonium and urea whereas uptake of nitrate was negligible. Uptake rates by well-fed cells of D. acuminata and D. acuta were $200 \%$ and $50 \%$ higher, respectively, than by starved cells. Uptake of urea by $D$. acuminata was significantly higher than that of ammonium in both nutritional conditions. In contrast, similar uptake rates of both compounds were observed in D. acuta. The apparent inability of Dinophysis to take up nitrate suggests the existence of incomplete nitrate-reducing and assimilatory pathways, in line with the paucity of nitrate transporter homologs in the D. acuminata reference transcriptome. Results derived from this study will contribute to understand Harmful Algal Blooms succession and differences in the spatio-temporal distribution of the two Dinophysis species when they co-occur in stratified scenarios.
\end{abstract}

Keywords: Dinophysis; nitrate; ammonium; urea; uptake rates; $\mathrm{N}^{15}$ incubations; antibiotic treatment

\section{Introduction}

Margalef [1] proposed a model, the well-known "Margalef's Mandala", with turbulence and concentration of inorganic nutrients as the main axes ordinating phytoplankton species into functional groups. Within the Mandala, a division was observed between phytoplankton species that thrived under high turbulence and nutrient concentrations (e.g., diatoms) and those that would succeed under low turbulence and low nutrient environments (e.g., dinoflagellates). Recently, Glibert [2] proposed an enhanced version of this Mandala, depicting the different phytoplankton functional types along 12 axes. The third axis of her version proposed a division between autotrophic and mixotrophic organisms, since it is now known that most phytoplankton species have a "somehow mixed nutritional behaviour" [3,4].

The term mixotrophy refers to an organism that relies on a combination of phototrophy and phagotrophy [5,6] and integrates a rather heterogenous group of organisms with diverse strategies [7]. Phototrophy in mixotrophs can include the use of light to generate chemical energy (ATP) and photoreductants (NADPH), and it may or may not involve uptake of dissolved $\mathrm{N}$ and $\mathrm{P}$ because sufficient amount of these elements may be provided by the ingestion of prey [8]. Mixotrophy, 
a widespread feeding behaviour within K-strategist phytoplankters (species with low growth rates that dominate under oligotrophic conditions; [1]), may provide a competitive advantage to endure harsh nutrient-limiting environmental conditions [5,9]. Most phototrophic microalgae, including facultative mixotrophs, can be maintained in laboratory cultures using enriched media with inorganic forms of $\mathrm{N}$, i.e., nitrate [10]. Among the mixotrophs, there are particular cases in which the main $\mathrm{N}$ contribution may be obtained from the prey, in this way saving energy to the predator. For example, $\sim 70 \%$ of $\mathrm{P}$ and $\mathrm{N}$ uptake of the haptophyte Prymnesium parvum has been reported to originate from its prey under deficiency of these nutrients [11].

Dinophysis species harbour "stolen" chloroplasts of cryptophyte origin [12] but such "kleptoplasts" are acquired through a vector organism, the phototrophic ciliate Mesodinium rubrum [13]. Phagocytosis of the ciliate prey by Dinophysis acuminata was found to contribute to around $50 \%$ of its daily carbon intake [14]. The question remained whether nitrogen supply in Dinophysis cells comes from dissolved nutrients or is obtained from their prey.

Several field studies indicated a preference for regenerated forms of nitrogen in Dinophysis acuminata (ammonium and organic molecules; [15-17]). These trends have been confirmed in laboratory incubations of D. acuminata $[18,19]$ which yielded no uptake, or fairly low rates, of inorganic forms of $\mathrm{N}$ and $\mathrm{P}$, but rapid assimilation of urea. All previous results suggested that Dinophysis is either a III B1 type of mixotroph (sensu [8]), i.e., "protists that retain chloroplasts and sometimes other organelles from one algal species or very closely related algal species", or a pSNMC (plastidic Specialist Non-Constitutive Mixotroph) [7].

Several species of Dinophysis are able to produce one or two groups of lipophilic toxins: (i) okadaic acid (OA) and dinophysistoxins (DTXs), also known as diarrhetic shellfish toxins and (ii) pectenotoxins (PTX) [20,21]. Diarrhetic shellfish toxins cause a gastrointestinal syndrome, Diarrhetic Shellfish Poisoning (DSP), a public health problem for shellfish consumers exposed to Dinophysis blooms [22,23]. Shellfish harvesting closures are enforced when toxin levels exceed the regulatory limits (160 $\mu \mathrm{g}$ toxin $\mathrm{kg}^{-1}$ flesh), causing considerable economic losses to the shellfish industry [24].

Monitoring of the main toxin-producing species of Dinophysis, D. acuminata and D. acuta, in the Galician Rías Baixas during the last three decades has revealed considerable interannual variability of Dinophysis blooms and DSP outbreaks. These two species bloom in different seasons: D. acuminata normally occurs from spring until late summer $[25,26]$, whereas $D$. acuta outbreaks are usually the result of advection of allochtonous populations in autumn [27,28]. Exceptionally, the latter may bloom, during very hot summers under a combination of persistent thermal stratification and moderate upwelling $[29,30]$. Different scenarios, promoting the bloom of one species or the other, have distinct nutrient regimes with contrasting contributions of new (nitrate from nutrient-rich upwelled waters) and regenerated production (ammonium and organic N sources) [31-33].

Reasons leading to the interannual and seasonal variability of the two species of Dinophysis in the Rías Baixas are not fully understood. Recently, two comparative studies of their responses to variable light and turbulence conditions have been performed [34,35], but their preferences for different nitrogen sources have not been examined so far. This information is of primary importance for the design of predictive models, including nitrogenous nutrient source-preferences, focused on the development of D. acuminata and D. acuta blooms in the Rías [36,37].

The objectives of the present study were i) to confirm the capacity of D. acuta and D. acuminata strains to take up dissolved nitrogenous (N) compounds; ii) to identify the preferential $\mathrm{N}$ source(s) for each species and iii) to determine interspecific differences in uptake rates of D. acuminata and D. acuta under well-fed and starved laboratory conditions. 


\section{Materials and Methods}

\subsection{Culture Conditions}

Dinophysis cultures were established from water samples collected in the Galician Rías Baixas (NW Spain): D. acuminata (VGO1349) was isolated in July 2016 from Ría de Vigo and D. acuta (VGO1065) in October 2010 from Ría de Pontevedra. The ciliate Mesodinium rubrum (AND-A0711) was isolated in 2007 from Huelva (SW Spain) and the cryptophyte Plagioselmis prolonga (CR10EHU), in 2003 from the Bay of Biscay (northern Spain). All cultures were grown in autoclaved seawater enriched with diluted (1:20) L1 (-Si) medium [38] to avoid outgrowth of cryptophytes, at pH $8.0 \pm 0.02$ and salinity 32. They were kept in a temperature controlled room at $15 \pm 1^{\circ} \mathrm{C}$, a 12:12 L:D cycle and an irradiance of $\sim 200 \mu \mathrm{mol}$ photons $\mathrm{m}^{-2} \mathrm{~s}^{-1}$ PAR provided by Osram Cool White 58W/640 fluorescent tubes. All cultures were non-axenic.

Prior to the experiments, D. acuminata and D. acuta were grown with diluted (1:20) L1 medium in glass flasks of increasing volumes (from $250 \mathrm{~mL}$ to $5 \mathrm{~L}$ and fed cryptophyte-free Mesodinium rubrum weekly at a 1:10 Dinophysis:Mesodinium ratio during 2 months to build up enough biomass for the experiments. After this period, Dinophysis cells were washed through a $20-\mu \mathrm{m}$ mesh, re-suspended in fresh medium and kept separately in 5 L flasks. Autoclaved aged seawater with salinity adjusted to 32 was used for all purposes throughout the pre- and experimental periods, and glassware previously washed with diluted (1:5) $\mathrm{HCl}$, rinsed with distilled water and dried to eliminate organic matter. Whatman GF/F (25 mm Ø, $0.7 \mu \mathrm{m}$ pore size) glass microfiber filters (Sigma-Aldrich, Munich, Germany) were precombusted at $\sim 450{ }^{\circ} \mathrm{C}$ in a muffle oven for $2 \mathrm{~h}$.

\subsection{Antibiotic Treatments}

Initial exposure of Dinophysis cultures to a full strength (1:1) filter-sterilized antibiotic cocktail containing $~ 5000$ penicillin units, $5 \mathrm{mg}$ streptomycin and $10 \mathrm{mg}$ neomycin $\mathrm{ml}^{-1}$ (Sigma-Aldrich, Germany), equivalent to $186 \mu \mathrm{L}$ of antibiotic solution per container, brought down the photosynthetic performance $\left(F_{v} / F_{m}=\right.$ maximum photochemical quantum yield of photosystem II) close to zero. In consequence, a diluted (1:2) concentration that did not decrease Fv/Fm values relative to the controls was used.

Fluorescence measurements ( $\phi Y(I I)$, photochemical quantum yield of the photosystem II) were carried out after $1 \mathrm{~h}$ incubation with a PAM (Pulse-Amplitude Modulation) fluorometer to monitor the photosynthetic state of the cells prior to the experiments. Simultaneously, a preliminary test with the same experimental conditions was set up to quantify the bacterial load reduction after the addition of antibiotics. Flow cytometry analyses were carried out with a BD FACS Aria III cell sorter, using triplicate subsamples $(15 \mathrm{~mL})$ from cultures of the two species, with and without antibiotics. Nucleic acids were stained using SYBR-green (Molecular Probes, Eugene, OR, USA).

\subsection{Background Nutrient Concentrations}

Dinophysis and Mesodinium cultures were scaled-up using diluted (1:20) L1 enrichment medium [38], with filtered $(0.22 \mu \mathrm{m})$ and autoclaved 1-year-aged seawater adjusted to a salinity of 32 .

Nutrient concentrations similar to natural seawater conditions in the Rías Baixas during an upwelling event [33,39] were complemented with trace additions of radio-labeled nitrogen isotopes. Ambient concentrations $\left(\mu \mathrm{mol} \cdot \mathrm{L}^{-1}\right.$ ) of $\mathrm{NO}_{3}{ }^{-}, \mathrm{NO}_{2}, \mathrm{NH}_{4}{ }^{+}$, and $\mathrm{CO}\left(\mathrm{NH}_{2}\right)_{2}$ in the seawater used for culture media were analyzed in six $50 \mathrm{~mL}$ samples (Table 1 ).

$\mathrm{NO}_{3}{ }^{-}, \mathrm{NO}_{2}$, and $\mathrm{NH}_{4}{ }^{+}$concentrations were determined by segmented flow analyses with Futura-Alliance autoanalyzers following [40] and $\mathrm{CO}\left(\mathrm{NH}_{2}\right)_{2}$, according to [41]. Analyses were carried out using an UV-2401 PC spectrophotometer Shimadzu (UV-VIS). Urea concentration was estimated by interpolation in the calibration line, the maximum of absorbance being at $524.80 \mathrm{~nm}$. 
Table 1. Background nutrient concentrations $\left(\mu \mathrm{mol} \cdot \mathrm{L}^{-1}\right)$ in the seawater used in Experiments 1 and 2.

\begin{tabular}{ccccccc}
\hline Label & $\mathrm{NO}_{3}{ }^{-}$ & $\mathrm{NO}_{2}$ & $\mathbf{N H}_{4}{ }^{+}$ & $\mathbf{P O}_{4}{ }^{3-}$ & $\mathbf{S i O}_{2}$ & $\mathbf{C O}\left(\mathbf{N H}_{2}\right)_{2}$ \\
\hline 1 & 2.58 & 0.68 & 0.96 & 0.22 & 5.21 & 0.14 \\
\hline 2 & 2.08 & 0.56 & 0.81 & 0.18 & 4.25 & 0.12 \\
\hline 3 & 2.23 & 0.60 & 0.85 & 0.18 & 4.43 & 0.08 \\
\hline 4 & 3.28 & 0.74 & 1.04 & 0.25 & 6.56 & 0.08 \\
\hline 5 & 2.30 & 0.51 & 0.77 & 0.19 & 4.57 & 0.08 \\
\hline 6 & 2.69 & 0.62 & 0.89 & 0.21 & 5.41 & 0.12 \\
\hline
\end{tabular}

\section{4. $\mathrm{N}^{15}$-Radiolabeled Stock Solutions}

Stock solutions with each nitrogen source were prepared with $100 \mathrm{~mL}$ of autoclaved seawater, salinity adjusted to 32, with the background nutrient concentrations described in Table 1. Additions of radiolabeled nitrogen sources were based on the difference between the concentrations described on Table 1 and those observed during upwelling events $\left(\sim 10 \mu \mathrm{mol} \cdot \mathrm{L}^{-1}\right.$ for nitrate, $\sim 3.5 \mu \mathrm{mol} \cdot \mathrm{L}^{-1}$ of ammonium and $\sim 0.5 \mu \mathrm{mol} \cdot \mathrm{L}^{-1}$ urea). Thus, tracer additions were $12.89 \mathrm{mg}$ of nitrate (Sodium nitrate- ${ }^{15} \mathrm{~N}, 98$ atom $\%{ }^{15} \mathrm{~N}$, Sigma-Aldrich, Germany), $3.70 \mathrm{mg}$ of urea (Urea- $-{ }^{15} \mathrm{~N}_{2}, 98$ atom $\%{ }^{15} \mathrm{~N}$, Sigma-Aldrich, Germany) and $1.08 \mathrm{mg}$ of ammonium (Ammonium- ${ }^{15} \mathrm{~N}_{2}$ sulfate, 98 atom $\%{ }^{15} \mathrm{~N}$, Sigma-Aldrich, Germany). These solutions were stored in polystyrene bottles of $500 \mathrm{~mL}$, kept in darkness and used for Experiments 1 and 2.

2.5. Nitrogen Uptake by Dinophysis acuminata and D. acuta in Well-Fed (Experiment 1) and Starved (Experiment 2) Conditions

\subsubsection{Experiment 1}

Well-fed washed cells of Dinophysis were inoculated, in triplicate, to reach an initial density of 200 cells $\mathrm{mL}^{-1}$ (200 mL total volume) in $500 \mathrm{~mL}$ polystyrene bottles (Corning, NY, USA) (Figure 1). Cultures were observed under the microscope to check Mesodinium cells were not present. After the incubations with antibiotics and PAM measurements, $6 \mathrm{~mL}$ of stock solution of the corresponding radiolabeled $\mathrm{N}$ compound was added to each treatment. After $3 \mathrm{~h}$ incubation and just before the filtration step, subsamples of $1.5 \mathrm{~mL}$ for cell counting under an inverted microscope (Nikon Eclipse, TE2000-S, Tokyo, Japan) were collected and fixed with Lugol's solution. Then, cultures were filtered, the filters dried overnight in an oven at $40^{\circ} \mathrm{C}$ and the dried filters kept in Eppendorf tubes.
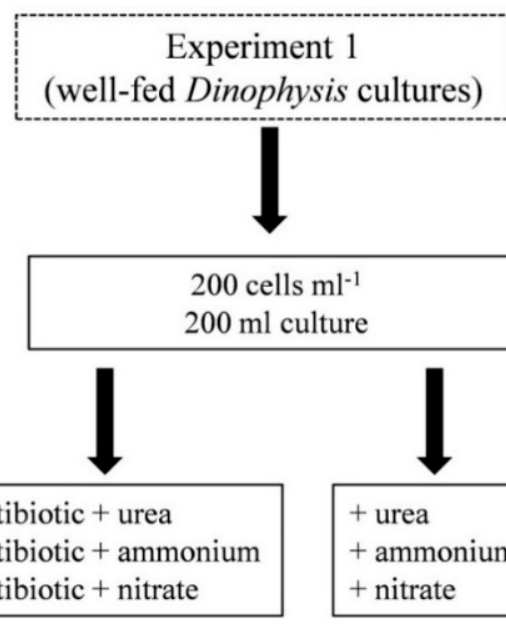
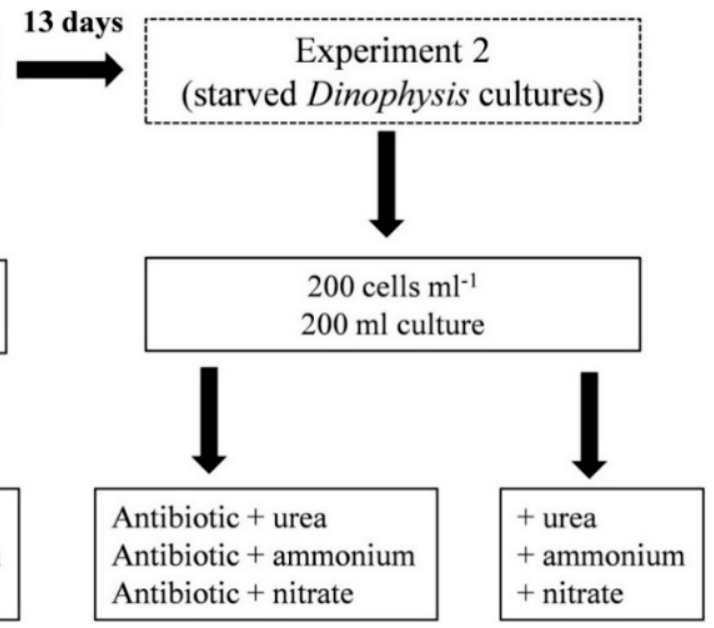

Figure 1. Diagram of the experimental design. 


\subsubsection{Experiment 2}

Dinophysis cells used were inoculated from the stock cultures. The initial conditions and procedures were the same as in Experiment 1. Time elapsed between Experiments 1 and 2 was 13 days (Figure 1).

\subsection{Nitrogen Isotope Analysis and Uptake Estimates}

Determination of $\delta^{15} \mathrm{~N}_{\text {AIR }}$ was carried out through sample combustion at $\sim 1020^{\circ} \mathrm{C}$ in an elementary analyser EA 1112-HT (Thermo, Massachusetts, USA). The generated combustion gases were purified and transferred to a Delta VAdvantage (Thermo, Massachusetts, EEUU) isotope ratio mass spectrometer (IRMS) through a Conflo III gas distribution system. International standards used were IAEA N2, IAEA 305-Be IAEA 311. JGOFS [42] protocols based on Dugdale and Goering [43] were used to measure ${ }^{15} \mathrm{~N}$ isotope tracer levels and estimate $\mathrm{N}$ uptake $\left(\mathrm{pmol} \mathrm{N}\right.$ cell ${ }^{-1} \mathrm{~h}^{-1}$ ) according to:

$$
\mathrm{N} \text { uptake }\left(\mathrm{nmol} \cdot \mathrm{L}^{-1} \cdot \mathrm{t}^{-1}\right)=\left({ }^{15} \mathrm{~N}_{\mathrm{xs}} \times \mathrm{PN}_{\mathrm{t}}\right) /\left({ }^{15} \mathrm{~N}_{\mathrm{enr}} \times \mathrm{t}\right)
$$

where $t$ is the incubation time (hours), ${ }^{15} \mathrm{~N}_{\mathrm{xs}}$ is the exceeding ${ }^{15} \mathrm{~N}$ (measured ${ }^{15} \mathrm{~N}$ minus ${ }^{15} \mathrm{~N}$ ambient level, 0.366 atom \%) in the post-incubation particle sample, $\mathrm{PN}_{\mathrm{t}}$ the particulate nitrogen content of the sample after incubation in units of nmol. $\mathrm{L}^{-1}$, and ${ }^{15} \mathrm{~N}_{\mathrm{enr}}$ the ${ }^{15} \mathrm{~N}$ enrichment in the dissolved fraction, estimated according to:

$$
{ }^{15} \mathrm{~N}_{\mathrm{enr}}=\left[\left(100 \times{ }^{15} \mathrm{~N}\right) /\left({ }^{15} \mathrm{~N}+{ }^{14} \mathrm{~N}\right)\right]-{ }^{15} \mathrm{~N}_{\mathrm{n}}
$$

where ${ }^{15} \mathrm{~N}$ is the concentration of labeled $\mathrm{N}, \mathrm{nmol} \cdot \mathrm{L}^{-1},{ }^{14} \mathrm{~N}$ the concentration (same units) of unlabeled $\mathrm{N}$ and ${ }^{15} \mathrm{~N}$ in the ambient level of ${ }^{15} \mathrm{~N}$. Cell counts were used in the transformation from $\mathrm{nmol} \cdot \mathrm{L}^{-1} \cdot \mathrm{t}^{-1}$ to pmol $\mathrm{N} \cdot \mathrm{cell}^{-1} \cdot \mathrm{h}^{-1}$.

\subsection{Reference Transcriptome of D. acuminata and Other Dinoflagellates}

Dinoflagellate reference transcriptomes from the Marine Microeukaryote Transcriptome Sequencing Project (MMETSP; [44]) were downloaded from Cyverse (http://www.cyverse.org). The reference corresponding to $A$. minutum was replaced by the one obtained by Le Gac et al. [45]. The 33 heterotrophic and photosynthetic dinoflagellates, including the only reference transcriptome available for Dinophysis (D. acuminata) were considered. For each reference transcriptome, a blastx homology analysis (e-value $<0.001)$ was performed against a custom database obtained using protein sequences with "nitrate reductase", "nitrite reductase", "nitrate transporter", "ammonium transporter", and "urease" in their name from the Uniprot/Swiss-Prot database (https:/www.uniprot.org/). For each type of proteins, Fisher Exact were performed to test if the number of homologs (taking into account the length of the transcriptome) in the D. acuminata reference transcriptome is similar to what is found overall in the other dinoflagellates.

\section{Results}

\subsection{Effect of Antibiotics in Dinophysis Cultures}

Dinophysis acuminata and D. acuta cells presented an intense red-pigmentation, normal morphology and swimming behaviour after the addition of a full (1:1) antibiotic solution. However, photosynthetic rates plummeted following $F v / F m$ measurements (data not shown) and thus, a diluted (1:2) cocktail solution was used instead. Dinophysis cultures treated with the diluted solution of antibiotics exhibited a bacterial load reduction of $17.74 \pm 1.86 \%(n=3)$.

Rapid light curves (RLCs) carried out with PAM-fluorometry showed that both cultures, with (treatments) and without (controls) antibiotics, were in good conditions. Changes in $\phi Y(I I)$ values through the eight PAR steps are shown in Figure 2. 

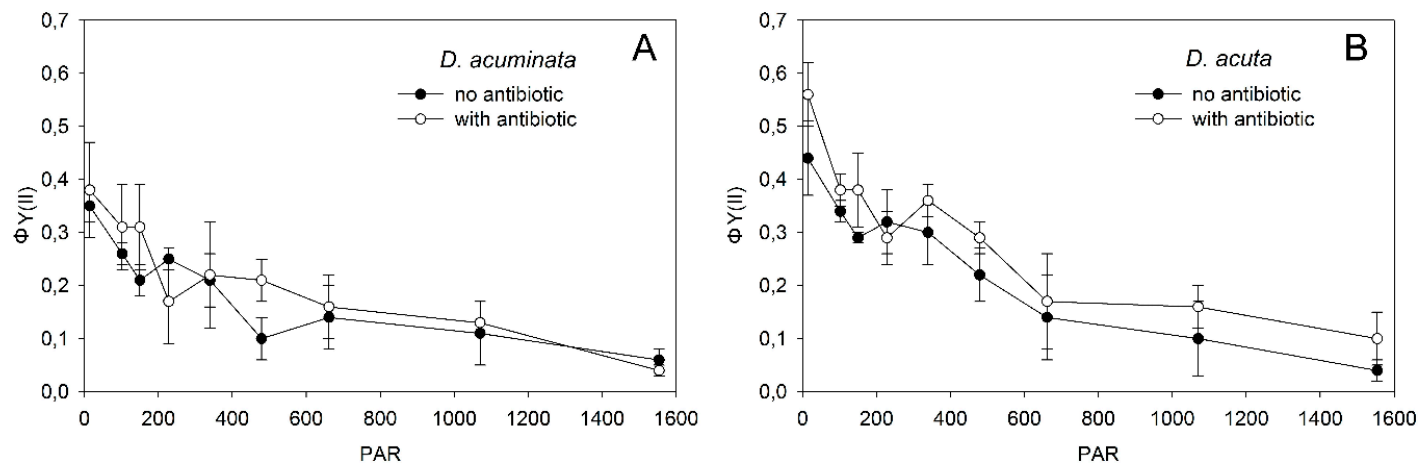

Figure 2. PAM rapid light curves (RLCs) of $\Phi$ PSII in A) Dinophysis acuminata and B) D. acuta triplicate cultures with (treatments) and without (controls) antibiotics with 8 different PAR conditions. Error bars represent standard deviations $(n=3)$.

\subsection{Uptake of Different N Sources by D. acuminata and D. acuta}

The nutritional status of the cells (well-fed/starved) significantly $(p<0.01)$ influenced the uptake of N sources in both species of Dinophysis. Uptake by well-fed cells of Dinophysis was always two- to threefold higher than by starved cells. The addition of antibiotics did not significantly affect $(p>0.3)$ the $\mathrm{N}$ uptake in any of the species (Table 2).

Table 2. Statistical significance of uptake rates of $\mathrm{N}$ sources by D. acuminata and D. acuta in well-fed and starved conditions, with and without antibiotics. 2w-ANOVA: two-way ANOVA. Asterisks $\left(^{*}\right)$ indicate high statistical significance.

\begin{tabular}{cccccc}
\hline \multirow{2}{*}{ Parameters } & \multirow{2}{*}{ Statistical Test } & \multicolumn{2}{c}{ D. acuminata } & \multicolumn{2}{c}{ D. acuta } \\
\cline { 3 - 6 } & & F-Value & $\boldsymbol{p}$-Value & F-Value & $\boldsymbol{p}$-Value \\
\hline Tracer & 2w-ANOVA & 147.21 & $3 \times 10^{-14 *}$ & 89.06 & $8 \times 10^{-12 *}$ \\
\hline Nutritional state & 2w-ANOVA & 76.56 & $24 \times 10^{-9 *}$ & 8.63 & $7 \times 10^{-3 *}$ \\
\hline Antibiotic & 2w-ANOVA & 0.99 & 0.33 & 0.00 & 0.99 \\
\hline Tracer:antibiotic & 2w-ANOVA & 3.73 & 0.04 & 0.93 & 0.41 \\
\hline Tracer:nutritional state & 2w-ANOVA & 17.31 & $2 \times 10^{-5 *}$ & 2.20 & 0.13 \\
\hline Antibiotic:nutritional state & 2w-ANOVA & 2.86 & $10^{-1}$ & 0.02 & 0.89 \\
\hline Nitrate-ammonium & TukeyHSD & & $10^{-7 *}$ & $10^{-7 *}$ \\
\hline Urea-ammonium & TukeyHSD & & $3 \times 10^{-3 *}$ & 0.64 \\
\hline Urea-nitrate & TukeyHSD & & $10^{-7 *}$ & $10^{-7 *}$ \\
\hline No antibiotic:antibiotic & TukeyHSD & & 0.33 & 0.99 \\
\hline Urea: well-fed-starved cells & TukeyHSD & & $3 \times 10^{-7 *}$ & 0.05 \\
\hline Ammonium: well-fed-starved cells & TukeyHSD & & $1 \times 10^{-5 *}$ & 0.41 \\
\hline Nitrate: well-fed-starved cells & TukeyHSD & & 0.99 & & 0.99 \\
\hline
\end{tabular}

In cultures of $D$. acuminata, ammonium and urea uptakes were up to 15-20-fold higher than those of nitrate $(p<0.01$, Tukey HSD, Table 2$)$, which were almost negligible. Urea was preferred to ammonium and their uptake rates were heavily affected by nutritional status $(p<0.01$, Tukey HSD, Table 2) (Table S1, Supplementary Materials; Figure 3). Significant differences were observed between well-fed compared with starved cells $(p<0.001$; Table 2$)$. Uptake of ammonium and urea by well-fed was significantly higher than by starved cells $(p<0.001)$ for urea and ammonium. 


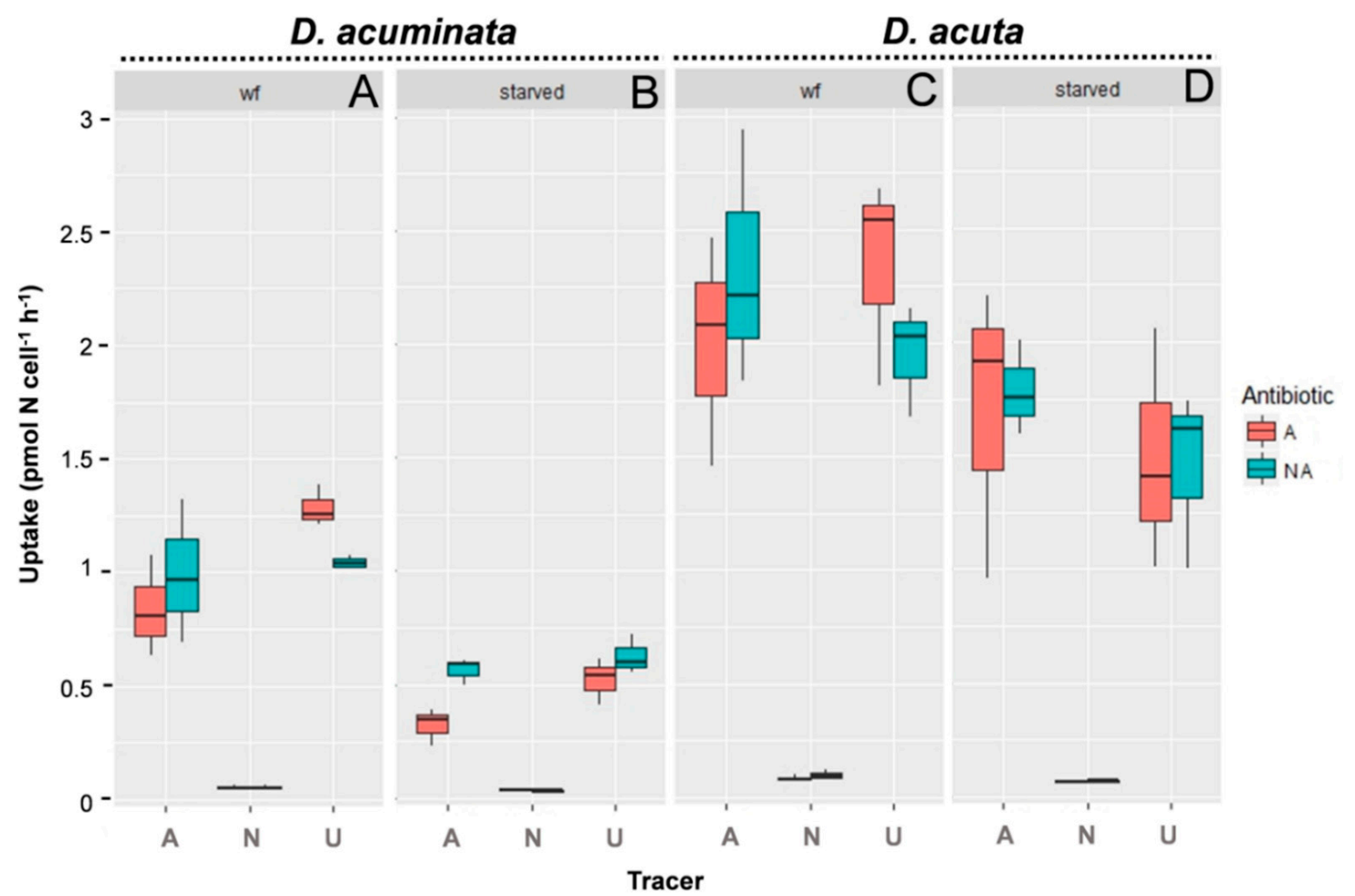

Figure 3. Uptake rates of different radio-labeled nitrogen sources (A: ammonium, N: nitrate and U: urea) by (A) well-fed and (B) starved cells of D. acuminata and by (C) well-fed and (D) starved cells of D. acuta., with antibiotics (A) or without antibiotics (N.A.) added.

In the case of D. acuta, uptake rates of ammonium and urea were also significantly higher than the estimated uptake of nitrate $(p<0.01$, Table 2$)$. However, there were no significant differences between uptake of ammonium and urea $(p=0.64$, Table 2$)$.

\subsection{Reference Transcriptome of D. acuminata}

Transcripts of transporter and reducer homologs involved in the absorption and assimilation of nitrogen compounds were retrieved from the reference transcriptomes of 33 dinoflagellates (Table S2, Supplementary Materials). Among them, the genus Dinophysis is represented by a single species, D. acuminata. Three heterotrophic species were also included (Crypthecodinium cohnii, Noctiluca scintillans, and Oxyhrris marina).

Our results showed that relative to the studied dataset, $D$. acuminata was strongly depleted in nitrate transporter homologs (Table $3 ; p<0.01$, odd ratio 0.3 ), accounting for the lowest value, only close to N. scintillans. Dinophysis acuminata also showed a slight depletion of nitrate reductase ( $p=0.01$, odd ratio 0.75 ) and ammonium transporter homologs ( $p=0.03$, odd ratio 0.57 ).

Table 3. Number of nitrate and nitrite reductase, nitrate and ammonium transporter, and urease homologs in the D. acuminata reference transcriptome. See methods for statistical analysis against a dataset of 32 dinoflagellates $(p<0.001)$.

\begin{tabular}{cccc}
\hline Protein Family & D. acuminata & Odd Ratio & $p$-Value \\
\hline Nitrate reductase & 77 & 0.75 & 0.01 \\
\hline Nitrite reductase & 13 & 0.65 & 0.14 \\
\hline Nitrate transporter & 8 & 0.3 & $4 \times 10^{-5}$ \\
\hline Ammonium transporter & 15 & 0.57 & 0.03 \\
\hline Urease & 42 & 0.95 & 0.8 \\
\hline
\end{tabular}




\section{Discussion}

\subsection{Preferences and Uptake of Nitrogenous Compounds by Dinophysis Species}

Earlier studies [15] reported a preference for regenerated forms of N (ammonium, urea) during incubation of field samples of a $D$. acuminata bloom with radiolabeled compounds in the southern Benguela upwelling system. Later, other authors [17] found a positive growth response after addition of $15 \mathrm{~N}$ labeled ammonium to field samples from Meeting-house Creek and Northport Bay, New York (USA) dominated by D. acuminata. A preference for ammonium was also found in D. acuminata cultures of a strain isolated from New York bay by the same authors when different $15 \mathrm{~N}$ labeled nitrogenous sources were provided [19].

There were differences between the experimental setup in Hattenrath-Lehmann and Gobler [19] and the present study. Culture volumes here were four times larger (200 vs. $50 \mathrm{~mL}$ ), the inoculum twice as dense (200 vs. 100 Dinophysis cells $\cdot \mathrm{mL}^{-1}$ ), the incubation time, according to JGOFS [42] protocols, three times higher ( 3 vs. $1 \mathrm{~h}$ ), and ${ }^{15} \mathrm{~N}$ tracer additions the same to well fed than to starved cultures of D. acuminata with a background concentration of nutrients similar to those in the Galician Rías during upwelling. In contrast, tracer additions were $180 \%$ and $4 \%$ of the ambient pools for ammonium, $70 \%$ and $140 \%$ for nitrate, and 50\% and $60 \%$ for urea for well fed and starved cultures, respectively, in Reference [19]. These authors referred to Collos and Harrison [46] to suggest a risk of cell intoxication in starved cultures in the presence of high concentrations of ammonium. In this regard, ammonium levels used in the present study $\left(3.5 \mu \mathrm{mol} \cdot \mathrm{L}^{-1}\right)$ were far from the average toxic levels for Dinophyceae (NH4 + NH3 = $1139 \pm 2494 \mu \mathrm{M})$ reported in Collos and Harrison [46] and also from the values considered to be toxic for Tripos furca $(20 \mu \mathrm{M})$ [47]. Parallel experiments with antibiotics to avoid interference due to bacterial metabolism failed to provide viable axenic cultures of Dinophysis. Hattenrath-Lehmann and Gobler [17] assumed a minimal contribution of bacteria during D. acuminata incubations, arguing that most of them would be eliminated in the filtration step. These authors observed Dinophysis cell mortality after the addition of antibiotics and discarded them in their experiments. In our case, cultures treated with antibiotic showed signs of photoinhibition if treated with full (1:1) or a minor reduction of the bacterial load if treated with diluted (1:2) antibiotic solution.

Despite large methodological differences between the two studies, results from incubations of strains of two species of Dinophysis from the Galician Rías with different ${ }^{15} \mathrm{~N}$-labeled nitrogen sources qualitatively agreed with those reported by Hattenrath-Lehmann et al. [17] with a strain of D. acuminata from New York. Dinophysis species from both experiments showed a clear preference for the most reduced (ammonium) inorganic and for the organic (urea) source of $\mathrm{N}$; their nitrate uptake was negligible. Concerning comparison between the two Galician species, D. acuminata, whether starved or well-fed, preferred urea to ammonium, whereas D. acuta showed similar uptake rates for both nutrients. In quantitative terms, uptake rates for ammonium and urea by D. acuta, a species with a cell volume 3.2 higher than D. acuminata [48], were proportional to their body size differences.

\subsection{Uptake Rates of Well-Fed versus Starved Cells of Dinophysis}

Nutritional status (well-fed vs. starved) of the cells appeared to be the most relevant (statistically significant) factor to the uptake rate of nitrogenous compounds in D. acuminata and D. acuta cultures.

There is a considerable body of literature about microalgal nutrient uptake. Nutrient deficiency and starvation have been related to enhanced maximum uptake rate [49], at least on short time scales [50]. These scales are in the range of those used $(<4 \mathrm{~h})$ in the ${ }^{15} \mathrm{~N}$ incubation experiments. However, the opposite seems to be true in Dinophysis cultures. Earlier experiments by Hattenrath-Lehmann and Gobler [19] found a fivefold higher uptake rate of ammonium in well-fed than in starved cells of D. acuminata and nearly no difference in the case of urea. The same trend was observed in Dinophysis acuminata from the Galician Rías, but rates for ammonium and urea were 2-fold and 6-fold higher, respectively, than those reported for the North American strains. 
The observations of declined $\mathrm{N}$ uptake rates with starved cells of Dinophysis, during short term $(2-4 \mathrm{~h})$ incubations with ${ }^{15} \mathrm{~N}$, may be explained by their nutritional behavior. Mixotrophic species of Dinophysis are obligate mixotrophs requiring light and prey for sustained growth [51]. In a recent classification, they were labeled as "plastidic specialists non-constitutive mixotroph" (pSNCM) requiring the plastids of a specific prey [7], the ciliate Mesodinium, itself a kleptoplastidic phototroph requiring cryptophyte flagellates belonging to the TPG (Teleaulax/Plagioselmis/Geminigera) clade [52]. Minnhagen et al. [53] concluded that starved cells of Dinophysis have a reduced photosynthetic capacity because their kleptoplastids pool gets diluted as cell division continues for $3-5$ generations without acquisition of new prey. Fritz et al. [54], using nitrate reductase immunolocalization with the dinoflagellate Lingulodinium polyedrum, showed that nitrate reduction was carried out in the chloroplasts. It seems plausible to expect that a smaller number of functionally impaired plastids in starved cells of Dinophysis would bring down their $\mathrm{N}$ assimilation capacity and biosynthetic activity. This view is supported by observations of a gradual decline of the photosynthetic performance in old kleptoplastids relative to that of the newly acquired in well-fed cells [55]. Recently, Rusterholz et al. [56] rejected the "dilution" theory and suggested a certain capacity of Dinophysis for kleptoplastid division, arguing in favour of a greater control than previously thought. In any case, starved condition led to a decline in kleptoplastid numbers per cell.

\subsection{Why D. acuminata and D. acuta Do Not Take Up Nitrate?}

The reduced number of nitrate transporter homologs detected in the single reference transcriptome of D. acuminata, much lower than in the rest of dinoflagellates in the dataset (with the exception of the heterotroph Noctiluca scintillans), points to poor nitrate transport into the cell, in agreement with culture and field observations, and potentially to the lack of a complete nitrate-reducing and assimilatory pathway.

In photosynthetic protists, nitrate assimilation is an active process performed first by transport into the cells and then by subsequent reduction steps. The enzyme Nitrate Reductase (NR) catalyzes the reduction step to nitrite, and the Nitrite Reductase (NiR) its reduction to ammonium ([57] and references therein). Urea is turned into $\mathrm{NH}_{3}{ }^{+} / \mathrm{NH}_{4}{ }^{+}$, released and assimilated inside the cell [58]. Ammonium $\left(\mathrm{NH}_{4}{ }^{+}\right)$is the easiest $\mathrm{N}$ form for dinoflagellates (and other primary producers) to acquire and transport into the cell since these processes require less energy [58,59], but concentrations above 25-50 $\mu \mathrm{m}$ may be toxic for some species [60-62].

The absence of most plastid-related genes in Dinophysis acuminata may be the reason this species cannot keep kleptoplasts permanently [63]. As illustrated in the present study, the depletion of nitrate metabolism related transcripts may explain its inability to assimilate nitrate. Taken together, while most dinoflagellates with permanent chloroplasts are able to grow if supplied strictly with inorganic nutrients, e.g., nitrate [10], mixotrophic organisms like Dinophysis can take up different proportions of $\mathrm{N}$ either by transporters or through heterotrophic feeding [64], thus compensating for the apparent inability to incorporate nitrate. It is already known that prey capture in Dinophysis provides an outstanding source of energy, and according to [14], that they need to cover about half of their carbon demand from prey ingestion for optimal growth. The proportions of $\mathrm{N}$ incorporated by each mechanism (photosynthesis versus phagotrophy) are unknown but it can be hypothesized that prey capture in Dinophysis is more relevant to this purpose than $\mathrm{N}$ transporters. This view is supported by the depletion of nitrate- and nitrite-reductase, but even more, by the low number of nitrate and ammonium transporter homologs (Table 3).

\subsection{Ecological Implications}

Dinophysis strains used in this study are from the Galician Rías Baixas (Muros, Arousa, Pontevedra, and Vigo), northernmost limit of the Canary Current Upwelling System and site of intensive raft-mussel cultivation (see, e.g., [65]). Upwelling events in spring and summer inject cold nitrate-rich waters into the Rías controlling nutrients and phytoplankton dynamics [66,67]; suspended mussels excrete 
plenty of ammonium and urea into the water column which is exploited by the phytoplankton community [68]. Large amounts of particulate matter are flushed out of the Rías in the upwelling season, and from sediments in the adjacent shelf where intense remineralization processes take place, in particular in summer; these regenerated nutrients may be reintroduced to the Rías with the shoreward upwelling currents. Nearly $70 \%$ of the mussel production $\left(2.5 \times 10^{6} \mathrm{t}\right.$ per year) takes place in Ría de Arousa, but morphology and bathymetry of this large ría favours more intense upwelling, shorter water residence times, maximal primary production, and minimal duration of harvesting closures for DSP toxins in the region [69]. Results from incubations with radiolabelled ${ }^{15} \mathrm{~N}$ during blooms of different toxin-producing microalgae in the Benguela and the Canary Current upwelling allowed Seeyave et al. $[15,16]$ to identify different nutrient acquisition strategies. Some species, such as Pseudo-nitzschia spp. (pennate diatoms) and the dinoflagellate Alexandrium catenella, which take up nitrate at a high rate, were classified as "velocity strategists", well adapted to exploit the new production from recently upwelled waters. In contrast, D. acuminata, with the highest affinity for ammonium, was considered an "affinity strategist", with adaptations to thrive in nitrogen-depleted waters. These observations agree with previous field observations and modeling simulations showing that the annual dinoflagellates maxima, including Dinophysis spp., occurred when there was a predominance of regenerated production [31,70]. This situation is common during downwelling at the end of the spring-summer upwelling season (the autumn transition) or within the short time scale (5-15 d) of upwelling-downwelling cycles in spring-summer [71].

Other authors (i.e., Reference [17]) added inorganic and organic radiolabelled N sources to incubations of field populations at the time of D. acuminata blooms in New York coastal waters. In microcosm experiments, Dinophysis populations increased after the addition of ammonium, urea, concentrated DON, and to a far lesser extent, nitrate. These results led them to conclude that $\mathrm{N}$-nutrients loading promoted growth and toxicity of D. acuminata.

Field observation in the rías and the moderate uptake rates of $\mathrm{N}$-compounds by Dinophysis species found in the present study support the views of Seeyave et al. [15]. Injection of nutrients following upwelling pulses triggers blooms of large centric diatoms followed by pennate diatoms [72,73]. When blooms of Pseudo-nitzschia co-occur with low biomass blooms of D. acuminata, they are vertically segregated: Pseudo-nitzschia cell maxima are in the pycnocline/nitrocline $(\sim 10 \mathrm{~m})$ and occasionally form thin layers, whereas the highest numbers of $D$. acuminata appear near the surface $(2-5 \mathrm{~m})$ (see, e.g., [74,75]). It seems highly improbable that Dinophysis species can outcompete diatoms in a N-nutrients uptake race. Their strategy relies on a combination of ciliate (Mesodinium spp) prey availability and hydrodynamic conditions favouring stratification. In fact, increased water residence times in the rías, related to a decline of upwelling-promoting northerly winds and higher water column stability, have been proposed as the key factors behind increased shellfish harvesting closures due to toxin contamination in the early 2000s [67]. A thermally stratified water column during July-August is also related with subsequent summer outbreaks of $D$. acuta in the Rías [30]. Therefore, physical factors (hydrodynamics) control the development, maintenance and decline of Dinophysis blooms in the Galician Rías. Vertical segregation of D. acuminata and D. acuta in the Galician Rías (the former close to the surface and the latter in the pycnocline) [75], and similar observations in D. acuminata and D. norvegica populations in the Baltic Sea [76], cannot be solely explained in terms of nutrient distributions alone. Attention must be paid to the match/mismatch of the different suites of environmental conditions (irradiance, turbulence, nutritional sources), optimal for Dinophysis and for its prey, the ciliate Mesodinium.

\section{Conclusions}

Dinophysis acuminata and D. acuta exhibited a preference for regenerated inorganic (ammonium) and organic (urea) sources of $\mathrm{N}$ during incubations of cultures of the two species in well-fed and starved conditions. Uptake rate of these $\mathrm{N}$ forms was reduced during starvation, in contrast with the typical uptake enhancement observed after refeeding food-limited microalgae. This is presumably due to weak 
kleptoplastid performance of prey-starved cells of mixotrophic species of Dinophysis. Screening of the different genes involved in $\mathrm{N}$ assimilation revealed a strong depletion of nitrate transporters in the $D$. acuminata reference transcriptome compared with other 32 dinoflagellates ( 29 photosynthetic and 3 heterotrophic ones). This is in agreement with our experimental data and with previous studies about the very low uptake of nitrate or even the lack of it and the high affinity for ammonium and urea. This is expected to be the case also for D. acuta and other members of this genus. These findings may help to explain the vertical segregation observed in field populations of Dinophysis in relation to the diatom populations during upwelling events. The reasons underlying these findings would merit new studies both in field and culture conditions to improve our understanding of the autoecology of these dinoflagellates and the possible evolution of their populations in the future.

Supplementary Materials: The following are available online at http://www.mdpi.com/2076-2607/8/2/187/s1.

Author Contributions: M.G.-P. participated in the experimental design, performed N uptake experiments and wrote the manuscript. M.L.G. carried out transcriptomic comparisons and co-wrote the manuscript, B.R. and J.G. co-wrote the manuscript. F.R. designed the study and co-wrote the manuscript. All authors have read and agreed to the published version of the manuscript.

Funding: This research was funded by Spanish projects DINOMA (RETOS Programme, CGL2013-48861-R) and PCIN-2015-252 (International Cooperation Programme) to participate in EC project MARBioFEED (ERA-NET Marine Biotechnology \# 068). This research article is part of the PhD thesis of M. García-Portela, supported with a $\mathrm{PhD}$ contract (BES-2014-067832). The two project grants and the PhD contract came from the Spanish Ministry of Economy, Industry and Competitiveness (MINEICO).

Acknowledgments: We thank Vanessa Peiró (Isotope Stable Laboratory, UAM, Madrid), Mercedes Peleteiro (CINBIO, UVigo) and Ana Virginia Filgueiras (IEO, Vigo) for technical support. M. García-Portela's thesis is appended to the "Marine Science, Technology and Management" (DO*MAR) doctoral programme at the University of Vigo.

Conflicts of Interest: The authors declare no conflict of interest.

\section{References}

1. Margalef, R. Life-forms of phytoplankton as survival alternatives in an unstable environment. Oceanol Acta 1978, 1, 493-509.

2. Glibert, P.M. Margalef revisited: A new phytoplankton mandala incorporating twelve dimensions, including nutritional physiology. Harmful Algae 2016, 55, 25-30. [CrossRef] [PubMed]

3. Raven, J.A.; Maberly, S.C. Phytoplankton Nutrition and Related Mixotrophy; Lickens, G.E., Ed.; Encyclopedia of Inland Waters; Elsevier: Oxford, UK, 2009; pp. 192-196.

4. Flynn, K.J.; Stoecker, D.K.; Mitra, A.; Raven, J.A.; Glibert, P.M.; Hansen, P.J.; Granéli, E.; Burkholder, J.M. Misuse of the phytoplankton-zooplankton dichotomy: The need to assign organisms as mixotrophs within plankton functional types. J. Plankt. Res. 2013, 35, 3-11. [CrossRef]

5. Stoecker, D.K. Mixotrophy in dinoflagellates. J. Eukaryot. Microbiol. 1999, 46, 397-401. [CrossRef]

6. Tittel, J.; Bissinger, V.; Zippel, B.; Gaedke, U.; Bell, E.; Lorke, A.; Kamjunke, N. Mixotrophs combine resource use to outcompete specialists: Implications for aquatic food webs. PNAS 2003, 100, 12776-12781. [CrossRef]

7. Mitra, A.; Flynn, K.J.; Tillmann, U.; Raven, J.A.; Caron, D.; Stoecker, D.K.; Not, F.; Hansen, P.J.; Hallegraeff, G.; Sanders, R.; et al. Defining planktonic protist functional groups on mechanisms for energy and nutrient acquisition: incorporation of diverse mixotrophic strategies. Protist 2016, 167, 106-120. [CrossRef]

8. Stoecker, D.K.; Hansen, P.J.; Caron, D.A.; Mitra, A. Mixotrophy in the marine plankton. Ann. Rev. Mar. Sci. 2017, 9, 311-335. [CrossRef]

9. Sanders, R.W. Mixotrophic protists in marine and freshwater ecosystems. J. Protozool. 1991, 38, 76-81. [CrossRef]

10. Hansen, P.J. The role of photosynthesis and food uptake for the growth of marine mixotrophic dinoflagellates. J. Eukaryot. Microb. 2011, 58, 203-214. [CrossRef]

11. Carvalho, W.F.; Granéli, E. Contribution of phagotrophy versus autotrophy to Prymnesium parvum growth under nitrogen and phosphorus sufficiency and deficiency. Harmful Algae 2010, 9, 105-115. [CrossRef]

12. Hackett, J.D.; Maranda, L.; Yoon, H.S.; Bhattacharya, D. Phylogenetic evidence for the cryptophyte origin of the plastid of Dinophysis (Dinophysiales, Dinophyceae). J. Phycol. 2003, 39, 440-448. [CrossRef] 
13. Park, M.G.; Kim, S.; Kim, H.S.; Myung, G.; Kang, Y.G.; Yih, W. First successful culture of the marine dinoflagellate Dinophysis acuminata. Aquat. Microb. Ecol. 2006, 45, 101-106. [CrossRef]

14. Hansen, P.J.; Nielsen, L.T.; Johnson, M.; Berge, T.; Flynn, K.J. Acquired phototrophy in Mesodinium and Dinophysis-A review of cellular organization, prey selectivity, nutrient uptake and bioenergetics. Harmful Algae 2013, 28, 126-139. [CrossRef]

15. Seeyave, S.; Probyn, T.A.; Pitcher, G.C.; Lucas, M.I.; Purdie, D.A. Nitrogen nutrition in assemblages dominated by Pseudo-nitzschia spp., Alexandrium catenella and Dinophysis acuminata off the west coast of South Africa. Mar. Ecol. Prog. Ser. 2009, 379, 91-107. [CrossRef]

16. Seeyave, S.; Probyn, T.; Álvarez-Salgado, X.A.; Figueiras, F.G.; Purdie, D.A.; Barton, E.D.; Lucas, M. Nitrogen uptake of phytoplankton assemblages under contrasting upwelling and downwelling conditions: The Ría de Vigo, NW Iberia. Estuar Coast Shelf Sci. 2013, 124, 1-12. [CrossRef]

17. Hattenrath-Lehmann, T.K.; Marcoval, M.A.; Mittlesdorf, H.; Goleski, J.A.; Wang, Z.; Haynes, B.; Morton, S.L.; Gobler, C.J. Nitrogenous nutrients promote the growth and toxicity of Dinophysis acuminata during estuarine bloom events. PLoS ONE 2015, 10, e0124148. [CrossRef]

18. Tong, M.; Smith, J.L.; Kulis, D.M.; Anderson, D.M. Role of dissolved nitrate and phosphate in isolates of Mesodinium rubrum and toxin-producing Dinophysis acuminata. Aquat. Microb. Ecol. 2015, 75, 169-185. [CrossRef]

19. Hattenrath-Lehmann, T.; Gobler, C.J. The contribution of inorganic and organic nutrients to the growth of a North American isolate of the mixotrophic dinoflagellate, Dinophysis acuminata. Limnol. Oceanogr. 2015, 60, 1588-1603. [CrossRef]

20. Yasumoto, T.; Oshima, Y.; Yamaguchi, M. Occurrence of a new type of shellfish poisoning in the Tohoku district. Bull Jpn. Soc. Sci. Fish 1978, 44, 1249-1255. [CrossRef]

21. Reguera, B.; Riobó, P.; Rodríguez, F.; Díaz, P.A.; Pizarro, G.; Paz, B.; Franco, J.M.; Blanco, J. Dinophysis toxins: Causative organisms, distribution and fate in shellfish. Mar. Drugs 2014, 12, 394-461. [CrossRef]

22. Yasumoto, T.; Murata, M.; Oshima, Y.; Sano, M.; Matsumoto, G.; Clardy, J. Diarrhetic shellfish toxins. Tetrahedron 1985, 41, 1019-1025. [CrossRef]

23. Lawrence, J.; Loreal, H.; Toyofuku, H.; Hess, P.; Iddya, K.; Ababouch, L. Assessment and Management of Biotoxin Risks in Bivalve Molluscs; FAO Fisheries and Aquaculture Technical Paper (551); FAO: Rome, Italy, 2011; p. 337.

24. O'Mahony, M. EU regulatory risk management of marine biotoxins in the marine bivalve mollusc food-chain. Toxins 2018, 10, 118. [CrossRef]

25. Reguera, B.; Bravo, I.; Mariño, J.; Campos-Loriz, M.J.; Fraga, S.; Carbonell, A. Trends in the occurrence of Dinophysis spp in Galician coastal waters. In Toxic Phytoplankton Blooms in the Sea; Smayda, T.J., Shimizu, Y., Eds.; Elsevier: Amsterdam, Netherlands, 1993; pp. 559-564.

26. Díaz, P.A.; Ruiz-Villarreal, M.; Velo-Suárez, L.; Ramilo, I.; Gentien, P.; Lunven, M.; Fernand, L.; Raine, R.; Reguera, B. Tidal and wind-event variability and the distribution of two groups of Pseudo-nitzschia species in an upwelling-influenced Ría. Deep Sea Res Part II: Top. Stud. Oceanogr. 2014, 101, 163-179. [CrossRef]

27. Escalera, L.; Reguera, B.; Moita, T.; Pazos, Y.; Cerejo, M.; Cabanas, J.M.; Ruiz-Villarreal, M. Bloom dynamics of Dinophysis acuta in an upwelling system: In situ growth versus transport. Harmful Algae 2010, 9, 312-322. [CrossRef]

28. Ruiz-Villarreal, M.; García-García, L.M.; Cobas, M.; Díaz, P.A.; Reguera, B. Modelling the hydrodynamic conditions associated with Dinophysis blooms in Galicia (NW Spain). Harmful Algae 2016, 53, 40-52. [CrossRef] [PubMed]

29. Reguera, B.; Bravo, I.; Fraga, S. Autoecology and some life history stages of Dinophysis acuta Ehrenberg. J. Plankton. Res. 1995, 17, 999-1015. [CrossRef]

30. Díaz, P.A.; Ruiz-Villarreal, M.; Pazos, Y.; Moita, T.; Reguera, B. Climate variability and Dinophysis acuta blooms in an upwelling system. Harmful Algae 2016, 53, 145-159. [CrossRef]

31. Ríos, A.F.; Fraga, F.; Figueiras, F.G.; Pérez, F.F. New and regenerated production in relation to the proliferations of diatoms and dinoflagellates in natural conditions. In Harmful Marine Algal Blooms; Lassus, P., Arzul, G., Erard, E., Gentien, P., Marcaillou, C., Eds.; Technique et Documentation-Lavoisier, Intercept Ltd.: Paris, France, 1995; pp. 663-668.

32. Doval, M.D.; López, A.; Madriñán, M. Spatio-temporal variability of inorganic and organic nutrients in five Galician rias (NW Spain). Sci. Mar. 2013, 77S1, 15e24. [CrossRef] 
33. Doval, M.D.; López, A.; Madriñán, M. Temporal variation and trends of inorganic nutrients in the coastal upwelling of the NW Spain (Atlantic Galician rías). J. Sea. Res. 2016, 108, 19-29. [CrossRef]

34. García-Portela, M.; Reguera, B.; Sibat, M.; Altenburger, A.; Rodríguez, F.; Hess, P. Metabolomic profiles of Dinophysis acuminata and Dinophysis acuta using non-targeted high-resolution mass spectrometry: effect of nutritional status and prey. Mar. Drugs 2018b, 16, 143. [CrossRef]

35. García-Portela, M.; Reguera, B.; d'Alcalà, M.R.; Rodríguez, F.; Montresor, M. Effects of small-scale turbulence on two species of Dinophysis. Harmful Algae 2019, 89, 101654. [CrossRef] [PubMed]

36. McGuillicudy, D.J., Jr.; Glibert, P.M.; Berdalet, E.; Edwards, C.; Franks, P.; Ross, O. GEOHAB Modelling, Linking Observations to Predictions. Available online: http://hab.ioc-unesco.org/index.php?option=com oe\&task=viewDocumentRecord\&docID=6659 (accessed on 17 December 2019).

37. Moita, T.; Pazos, Y.; Rocha, C.; Nolasco, R.; Oliveira, P.B. Toward predicting Dinophysis blooms off NW Iberia: A decade of events. Harmful Algae 2016, 53, 17-32. [CrossRef] [PubMed]

38. Guillard, R.R.L.; Hargraves, P.E. Stichochrysis immobilis is a diatom, not a chrysophyte. Phycologia 1993, 32, 234-236. [CrossRef]

39. Álvarez-Salgado, X.A.; Doval, M.D.; Pérez, F.F. Dissolved organic matter in shelf waters off the Ría de Vigo (NW Iberian upwelling system). J. Mar. Syst. 1999, 18, 383-394. [CrossRef]

40. Hansen, H.P.; Grasshoff, K. Automated chemical analysis. In Methods of Seawater Analysis, 2nd ed.; Grasshoff, K., Ehrhardt, M., Kremling, K., Eds.; Verl. Chemie: Weinheim, Germany, 1983; pp. 347-379.

41. Goeyens, L.; Semeneh, M.; Elskens, M.; Shopova, D.; Baumann, M.E.M.; Dehairs, F. Phytoplankton nutrient utilisation and nutrient signature in the Southern Ocean. J. Mar.Syst. 1998, 17, 143-157. [CrossRef]

42. UNESCO. Protocol for the Joint Global Ocean Flux Study (JGOFS) Core Measurements. (IOC Manuals and Guides No. 29); UNESCO-IOC: Paris, France, 1994; pp. 130-135.

43. Dugdale, R.C.; Goering, J.J. Uptake of new and regenerated forms of nitrogen in primary productivity 1. Limnol. Oceanogr. 1967, 12, 196-206. [CrossRef]

44. Keeling, P.J.; Burki, F.; Wilcox, H.M.; Allam, B.; Allen, E.E.; Amaral-Zettler, L.A.; Armbrust, E.V.; Archibald, J.M.; Bharti, A.K.; Bell, C.J. The Marine Microbial Eukaryote Transcriptome Sequencing Project (MMETSP): Illuminating the functional diversity of eukaryotic life in the oceans through transcriptome sequencing. PLoS Biol. 2014, 12, e1001889. [CrossRef]

45. Le Gac, M.; Metegnier, G.; Chomérat, N.; Malestroit, P.; Quéré, J.; Bouchez, O.; Siano, R.; Destombe, C.; Guillou, R.; Chapelle, A. Evolutionary processes and cellular functions underlying divergence in Alexandrium minutum. Mol. Ecol. 2016, 25, 5129-5143. [CrossRef]

46. Collos, Y.; Harrison, P.J. Acclimation and toxicity of high ammonium concentrations to unicellular algae. Mar. Poll. Bull. 2014, 80, 8-23. [CrossRef]

47. Baek, S.H.; Shimode, S.; Han, M.S.; Kikuchi, T. Growth of dinoflagellates, Ceratium furca and Ceratium fusus in Sagami Bay, Japan: the role of nutrients. Harmful algae 2008, 7, 729-739. [CrossRef]

48. García-Portela, M.; Riobó, P.; Reguera, B.; Garrido, J.L.; Blanco, J.; Rodríguez, F. Comparative ecophysiology of Dinophysis acuminata and D. acuta (DINOPHYCEAE, DINOPHYSIALES): Effect of light intensity and quality on growth, cellular toxin content, and photosynthesis. J. Phycol. 2018a, 54, 899-917.

49. Syrett, P.J. The assimilation of ammonia and nitrate by nitrogen-starved cells of Chlorella vulgaris. 11. The assimilation of large quantities of nitrogen. Physiol. Plant. 1956, 9, 19. [CrossRef]

50. Collos, Y. Transient situations in nitrate assimilation by marine diatoms. 1. Changes in uptake parameters during nitrogen starvation 1. Limnol. Oceanogr. 1980, 25, 1075-1081. [CrossRef]

51. Kim, S.; Kang, Y.G.; Kim, H.S.; Yih, W.; Coats, D.W.; Park, M.G. Growth and grazing responses of the mixotrophic dinoflagellate Dinophysis acuminata as functions of light intensity and prey concentration. Aquat. Microb. Ecol. 2008, 51, 301-310. [CrossRef]

52. Johnson, M.D.; Beaudoin, D.J.; Laza-Martínez, A.; Dyhrman, S.T.; Fensin, E.; Lin, S.; Merculief, A.; Nagai, S.; Pompeu, M.; Setälä, O. The genetic diversity of Mesodinium and associated Cryptophytes. Front. Microbiol. 2016, 7, 2017. [CrossRef]

53. Minnhagen, S.; Kim, M.; Salomon, P.; Yih, W.; Granéli, E.; Park, M.G. Active uptake of kleptoplastids by Dinophysis caudata from its ciliate prey Myrionecta rubra. Aquat. Microb. Ecol. 2011, 62, 99-108. [CrossRef]

54. Fritz, L.; Stringher, C.G.; Colepicolo, P. Immunolocalization of nitrate reductase in the marine dinoflagellate gonyaulax polyedra (pyrrophyta) 1. J. Phycol. 1996, 32, 632-637. [CrossRef] 
55. Park, M.G.; Park, J.S.; Kim, M.; Yih, W. Plastid dynamics during survival of Dinophysis caudata without its ciliate prey. J. Phycol. 2008, 44, 1154-1163. [CrossRef]

56. Rusterholz, P.M.; Hansen, P.J.; Daugbjerg, N. Evolutionary transition towards permanent chloroplasts?-Division of kleptochloroplasts in starved cells of two species of Dinophysis (Dinophyceae). PloS ONE 2017, 12, e0177512. [CrossRef]

57. Sanz-Luque, E.; Chamizo-Ampudia, A.; Llamas, A.; Galvan, A.; Fernandez, E. Understanding nitrate assimilation and its regulation in microalgae. Front. Plant. Sci. 2015, 6, 899. [CrossRef]

58. Collos, Y.; Berges, J.A. Nitrogen metabolism in phytoplankton. In Encyclopedia of Life Support Systems; Duarte, C.M., Ed.; EOLSS Publishers: Paris, France, 2003.

59. Raven, J.A. A cost-benefit analysis of photon absorbtion by photosynthetic unicells. New Phytol. 1984, 98, 593-625. [CrossRef]

60. Chang, F.H.; McClean, M. Growth responses of Alexandrium minutum (Dinophyceae) as a function of three different nitrogen sources and irradiance. N. Z. J. Mar. Freshw Res. 1997, 31, 1-7. [CrossRef]

61. Leong, S.C.Y.; Taguchi, S. Response of the dinoflagellate Alexandrium tamarense to a range of nitrogen sources and concentrations: growth rate, chemical carbon and nitrogen, and pigments. Hydrobiologia 2004, 515, 215-224. [CrossRef]

62. Lee, Y.S. Utilization of various nitrogen, phosphorus, and selenium compounds by Cochlodinium polykrikoides. J. Environ. Biol. 2008, 29, 799-804. [PubMed]

63. Wisecaver, J.H.; Hackett, J.D. Transcriptome analysis reveals nuclear-encoded proteins for the maintenance of temporary plastids in the dinoflagellate Dinophysis acuminata. BMC Genom. 2010, 11, 366. [CrossRef] [PubMed]

64. Dagenais-Bellefeuille, S.; Morse, D. Putting the N in dinoflagellates. Front Microbiol. 2013, 4, 369. [CrossRef] [PubMed]

65. Pérez-Camacho, A.; González, R.; Fuentes, J. Mussel culture in Galicia (NW Spain). Aquaculture 1991, 94, 263-278. [CrossRef]

66. Figueiras, F.G.; Wyatt, T.; Alvarez-Salgado, X.A.; Jenkinson, I.R. Advection, diffusion and patch development in the Rias Baixas. In Harmful Marine Algal Blooms; Lassus, P., Arzul, G., Erard, E., Gentien, P., Marcaillou, C., Eds.; Technique et Documentation-Lavoisier, Intercept Ltd.: Paris, France, 1995; pp. 579-584.

67. Álvarez-Salgado, X.A.; Labarta, U.; Fernández-Reiriz, M.J.; Figueiras, F.G.; Rosón, G.; Piedracoba, S.; Filgueira, R.; Cabanas, J.M. Renewal time and the impact of harmful algal blooms on the extensive mussel raft culture of the Iberian coastal upwelling system (SW Europe). Harmful Algae 2008, 7, 849-855. [CrossRef]

68. Álvarez-Salgado, X.A.; Rosón, G.; Pérez, F.F.; Figueiras, F.G.; Pazos, Y. Nitrogen cycling in an estuarine upwelling system, the Ría de Arousa (NW, Spain). I. Short-time-scale patterns of hydrodynamic and biogeochemical circulation. Mar. Ecol. Prog. Ser. 1996, 135, 259-273. [CrossRef]

69. Blanco, J.; Correa, J.; Muñíz, S.; Mariño, C.; Martín, H.; Arévalo, A. Evaluación del impacto de los métodos y niveles utilizados para el control de toxinas en el mejillón. Revista Galega dos Recursos Mariños (Art. Inf. Tecn.) 2013, 3, 1-55.

70. Figueiras, F.G.; Ríos, A.F. Phytoplankton succession, red tides and hydrographic regime in the Rías Bajas of Galicia. In Toxic Phytoplankton Blooms in the Sea; Smayda, J., Shimizu, Y., Eds.; Elsevier: New York, NY, USA, 1993; pp. 239-244.

71. Álvarez-Salgado, X.A.; Gago, J.; Míguez, B.M.; Gilcoto, M.; Pérez, F.F. Surface waters of the NW Iberian margin: Upwelling on the shelf versus outwelling of upwelled waters from the Rías Baixas. Estuar. Coast Shelf Sci. 2000, 51, 821-837. [CrossRef]

72. Nogueira, E.; Ibañez, F.; Figueiras, F.G. Effect of meteorological and hydrographic disturbances on the microplankton community structure in the Ría de Vigo (NW Spain). Mar. Ecol. Prog. Ser. 2000, 203, $23-45$. [CrossRef]

73. Tilstone, G.H.; Miguez, B.M.; Figueiras, F.G.; Fermín, E.G. Diatom dynamics in a coastal ecosystem affected by upwelling: Coupling between species succession, circulation and biogeochemical processes. Mar. Ecol. Prog. Ser. 2000, 205, 23-41. [CrossRef]

74. Velo-Suárez, L.; González-Gil, S.; Gentien, P.; Lunven, M.; Bechemin, C.; Fernand, L.; Raine, R.; Reguera, B. Thin layers of Pseudonitzschia spp. and the fate of Dinophysis acuminata during an upwelling-downwelling cycle in a Galician Ría. Limnol. Oceanogr. 2008, 53, 1816. [CrossRef] 
75. Díaz, P.A.; Ruiz-Villarreal, M.; Mouriño-Carballido, B.; Fernández-Pena, C.; Riobó, P.; Reguera, B. Fine scale physical-biological interactions during a shift from relaxation to upwelling with a focus on Dinophysis acuminata and its potential ciliate prey. Progr. Oceanogr. 2019, 175, 309-327. [CrossRef]

76. Hällfors, H.; Hajdu, S.; Kuosa, H.; Larsson, U. Vertical and temporal distribution of the dinoflagellates Dinophysis acuminata and D. norvegica in the Baltic Sea. Boreal. Environ. Res. 2011, 16, 121-135.

(C) 2020 by the authors. Licensee MDPI, Basel, Switzerland. This article is an open access article distributed under the terms and conditions of the Creative Commons Attribution (CC BY) license (http://creativecommons.org/licenses/by/4.0/). 